\title{
A survey on the knowledge, perceptions and practices regarding unwanted medicine disposal among pharmacists in Sri Lanka
}

\author{
Vipula R. Bataduwaarachchi*, Chamari L. Weerarathna, A. Paherathy, Dinuka S. Warapitiya, \\ Mythili Sivapathasundaram, Thilini N. Wickramarathna, I. U. Haputhanthrige, \\ Maheshi D. Wijayabandara, T. Rameshkumar
}

Department of Pharmacology, Faculty of Medicine, University of Colombo, Sri Lanka

\author{
Received: 10 February 2020 \\ Revised: 29 April 2020 \\ Accepted: 30 April 2020 \\ *Correspondence: \\ Dr. Vipula R. Bataduwaarachchi, \\ Email: vipbat7@yahoo.com
}

Copyright: () the author(s), publisher and licensee Medip Academy. This is an open-access article distributed under the terms of the Creative Commons Attribution Non-Commercial License, which permits unrestricted non-commercial use, distribution, and reproduction in any medium, provided the original work is properly cited.

\begin{abstract}
Background: Unwanted medicines are defined as expired, unused, damaged or contaminated pharmaceutical products. Improper disposal of unwanted medicines leads to many health and environmental hazards. The World Health Organisation recommends that unwanted medicines should always be disposed properly. The main objective of this study was to assess the knowledge, practices and perceptions on the disposal of unwanted medicines among pharmacists in Sri Lanka.

Methods: A cross-sectional study was carried out among pharmacists in 40 private retail pharmacies in the Northern, Eastern and the Western provinces within a period of three months. The pharmacies were selected via stratified randomised sampling in each district. The most experienced pharmacist in each pharmacy was recruited for data collection. A pre-tested, self-administered questionnaire was used. The ethics approval was obtained (Ref: EC-12190). The data was represented using simple descriptive statistics.

Results: The data was collected from 40 pharmacies. Among the pharmacists, $65 \%$ were males. The majority answered that burning and landfill as the most appropriate methods of disposal for most of the types of medicinal waste. A significant number of pharmacists were not aware about the method of disposal for anti-infective agents and anti-neoplastic agents. The majority perceived the seriousness of environmental damage caused by disposal via trash or sink. A majority was not agreeing to have pharmacies as collecting centers for unwanted medicines. A discrepancy between the pharmacists' perceptions and the practices was observed.

Conclusions: The level of knowledge, practices and perceptions among pharmacists on unwanted medicines disposal was substandard and needs attention.
\end{abstract}

Keywords: Medication waste disposal, Pharmaceutical waste, Unwanted medicines

\section{INTRODUCTION}

Unwanted medicines (UM) are defined as expired, unused, damaged or contaminated pharmaceutical products which are no longer required. ${ }^{1}$ Improper disposal of UM leads to many health and environmental hazards such as poisoning, air pollution, contamination of water and food sources etc. The presence of pharmaceutical products in the environment has been confirmed by ecological studies worldwide. ${ }^{2}$ The World Health Organisation (WHO) recommends that UM should always be considered as pharmaceutical waste and should never be utilised for humans and animals. ${ }^{3}$ Most of the Western countries have developed their own guidelines on UM disposal. In Sweden, there is a system to return unused medicine to pharmacies from the public, 
thereafter, destruction is carried out using incineration. ${ }^{4}$ In New Zealand, although there are official guidelines on handing UM, the public is instructed to return UM to pharmacies. ${ }^{5}$ In Kuwait, pharmacies are required to return UM to the central stores, which dispose them according to the procedures of the environment public authority. ${ }^{6}$ Studies exploring UM disposal practices are limited among developing countries. There has been little analysis with regard to practices and attitudes of pharmacists with regard to the disposal of UM. ${ }^{7}$

In Sri Lanka, the cosmetic, devices and drugs act (CDDA) recommends destroying UM under supervision of an authorised officer. However, it does not provide a comprehensive guidance on specific situations. This paper assesses the knowledge, practices and perceptions on the disposal of UM among pharmacists in Sri Lanka. The findings of this study would help health policy makers, health administrators, and other stakeholders involved in this process to identify deficits, enabling improvement and strengthening of the process.

\section{METHODS}

A cross-sectional study was carried out among pharmacists in private retail pharmacies in Northern, Eastern and Western provinces of Sri Lanka within a period of three months (from June 2017 to July 2017). The private retail pharmacy outlets were selected based on the "measuring medicine prices, availability, affordability and price components" guidance published by the WHO. The survey was conducted in the Northern, Eastern and the Western provinces, each covering more than 100,000 population as indicated in the WHO recommendations. Stratified randomised sampling was performed to select pharmacies from the latest list of registered private pharmacies in each district. In the districts, where the population exceeds 1 Million, two sets of samples were collected. Each set consisted of five private retail pharmacies and this added to the total estimated sample size of 40 pharmacies. In case of refusal, a new pharmacy was selected from the same list until the required total sample size was reached. The pharmacist who had the most working experience in the pharmacy was recruited for data collection. Informed consent was obtained from each participant. The data collection was done using a pre-tested, self-administered questionnaire. The database was created using the SPSS version 21.0 and the data was represented using simple descriptive statistics.

\section{RESULTS}

\section{Demography of the sample}

The data collection was completed in 40 pharmacies from the Northern $(n=12)$, the Eastern $(n=9)$ and the Western (19) provinces. Among the pharmacists, the majority (65\%) was males and more than $75 \%$ of the participants had accepted level of qualifications (Table 1).
Table 1: Demographic details of the pharmacists $(n=40)$.

\begin{tabular}{|lll|}
\hline Characteristics & \multicolumn{2}{|l|}{ N $(\%)$} \\
\hline \multirow{2}{*}{ Sex } & 40.8 years (20-73) \\
\hline $\begin{array}{l}\text { Male } \\
\text { Duration of service } \\
\text { as a pharmacist }\end{array}$ & Female & $26(65)$ \\
\hline \multirow{2}{*}{$\begin{array}{l}\text { Not responded } \\
\text { Qualifications in } \\
\text { pharmacy }\end{array}$} & $\begin{array}{l}\text { Local degree } \\
\text { (non-pharmacy) }\end{array}$ & $2(5)$ \\
\cline { 2 - 3 } & $\begin{array}{l}\text { Internal pharmacy } \\
\text { course }\end{array}$ & $6(15)$ \\
\cline { 2 - 3 } & $\begin{array}{l}\text { External pharmacy } \\
\text { examination }\end{array}$ & $24(60)$ \\
\hline & $\begin{array}{l}\text { Other (MBBS) } \\
\text { Not responded }\end{array}$ & $7(2.5)$ \\
\hline
\end{tabular}

\section{Knowledge of pharmacists on UM disposal}

Regarding the disposal methods for different types of medicinal waste, nearly a $30 \%$ responded 'returning to the company' as the suitable method, while more than $50 \%$ thought otherwise. The majority thought burning and landfill as the most appropriate methods of disposal for most types of waste, while more than $20 \%$ were unaware about any method of disposal. A significant number of pharmacists were not aware about the method of disposal for anti-infective agents and anti-neoplastic agents which need special precautions to be followed during handling and disposal (Table 2).

\section{Practice of disposal methods by pharmacists}

The most common methods to dispose UM were 'returning to companies', followed by 'discarding in landfill' and 'burning'. A majority of participants had marked the disposal method as 'by other methods,' however, lack of data on the exact method was a drawback in this study. A great variation was observed for the practice of disposal for different type of waste among pharmacists (Table 3).

\section{Perceptions of the pharmacists and the preparedness to accept $U M$ at pharmacies}

The majority accepted that the disposal via trash or sink causes serious environmental damage (Table 4). Although, the majority was willing to have a national scheme for UM management, they were not agreeing to have pharmacies as the collecting centers for unwanted medicines. Although, most of the pharmacies (60\%) used to conduct annual audits, there was no sorting mechanism for UM before disposal. A majority reported that they have a separate area to store UM. However, most pharmacists $(65 \%)$ reported that they do not accept UM at all (Table 5). A discrepancy between the perceptions and the practices on UM handing was observed. 
Table 2: Knowledge on the disposal methods for UM by pharmacists.

\begin{tabular}{|c|c|c|c|c|c|c|c|c|c|c|}
\hline 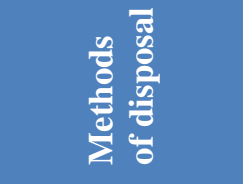 & $\frac{\sqrt[0]{0}}{\underbrace{2}}$ & 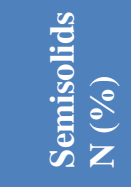 & $\underbrace{\frac{2}{3}}_{0} \underbrace{2}$ & $\frac{\sqrt[c]{3}}{\sqrt[3]{3}}$ & 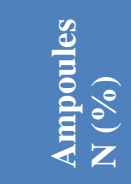 & 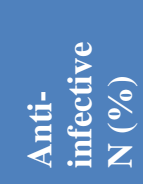 & 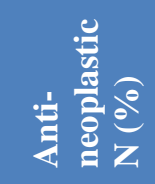 & 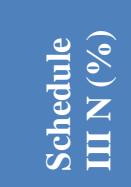 & $\frac{0}{8} \frac{8}{8}$ & $\frac{e_{0}^{0}}{\sqrt[3]{2}}$ \\
\hline $\begin{array}{l}\text { Return to } \\
\text { company } \\
\text { through agents }\end{array}$ & $11(31)$ & $9(26)$ & $8(21)$ & $9(25)$ & $8(26)$ & $10(32)$ & $9(32)$ & $9(32)$ & $10(31)$ & $11(31)$ \\
\hline $\begin{array}{l}\text { Other } \\
\text { methods }\end{array}$ & $22(61)$ & $22(65)$ & $20(59)$ & $21(67)$ & $20(65)$ & $18(58)$ & $12(43)$ & $13(46)$ & $14(44)$ & $17(49)$ \\
\hline Burn & $9(25)$ & $8(24)$ & $6(15)$ & $6(17)$ & $5(16)$ & $10(32)$ & $7(25)$ & $4(14)$ & $11(34)$ & $12(34)$ \\
\hline Landfill & $8(22)$ & $9(26)$ & $7(18)$ & $10(28)$ & $5(16)$ & $3(10)$ & $4(14)$ & $8(29)$ & & \\
\hline $\begin{array}{l}\text { Use as } \\
\text { chemicals }\end{array}$ & $2(6)$ & $2(6)$ & $1(3)$ & $1(3)$ & $1(6)$ & $2(6)$ & $1(4)$ & $1(4)$ & - & - \\
\hline $\begin{array}{l}\text { Give to } \\
\text { municipal } \\
\text { council }\end{array}$ & $3(8)$ & $3(9)$ & $3(8)$ & $3(8)$ & - & - & - & - & - & $2(6)$ \\
\hline Toilet/sink & - & - & $3(8)$ & $1(3)$ & - & - & - & - & - & - \\
\hline Recycling & - & - & & & $8(26)$ & - & - & - & $3(9)$ & $2(6)$ \\
\hline Other & - & - & $3(8)$ & - & $1(3)$ & $3(10)$ & - & - & & $1(3)$ \\
\hline Do not know & $3(8)$ & $3(9)$ & $5(13)$ & $3(8)$ & $3(10)$ & $3(10)$ & $7(25)$ & $6(21)$ & $8(25)$ & $7(20)$ \\
\hline $\begin{array}{l}\text { Total } \\
\text { responding }\end{array}$ & 36 & 34 & 39 & 36 & 31 & 31 & 28 & 28 & 32 & 35 \\
\hline
\end{tabular}

Table 3: Disposal methods of UM by pharmacists.

\begin{tabular}{|c|c|c|c|c|c|c|c|c|c|c|c|}
\hline 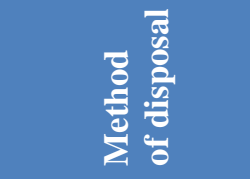 & 응 莺 & 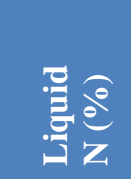 & 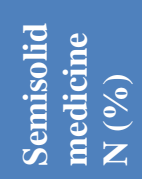 & 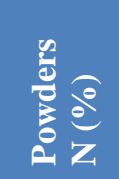 & 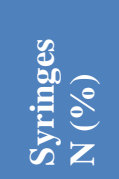 & 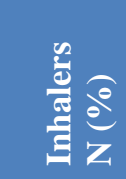 & 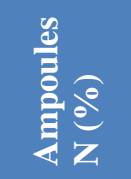 & 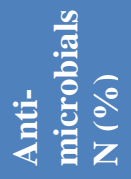 & 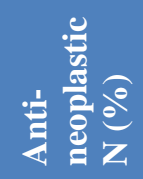 & 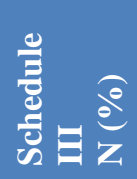 & 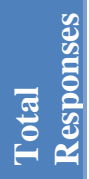 \\
\hline Rubbish bin & $3(8)$ & $2(5)$ & $3(8)$ & $3(8)$ & $1(3)$ & $1(3)$ & $5(13)$ & $2(5)$ & - & - & 20 \\
\hline Sink & $3(8)$ & $3(8)$ & - & $1(3)$ & - & - & - & - & - & - & 7 \\
\hline Toilet & $3(8)$ & $4(10)$ & $1(3)$ & $2(5)$ & - & $1(3)$ & $1(3)$ & - & - & - & 12 \\
\hline Landfill & $9(23)$ & $14(35)$ & $11(28)$ & $13(33)$ & $4(10)$ & $6(15)$ & $11(28)$ & $8(20)$ & $5(13)$ & $8(20)$ & 89 \\
\hline $\begin{array}{l}\text { Crush and } \\
\text { flush }\end{array}$ & $1(3)$ & - & $2(5)$ & $2(5)$ & $3(8)$ & $2(5)$ & $3(8)$ & $1(3)$ & - & $1(3)$ & 15 \\
\hline Burn & $11(28)$ & $4(10)$ & $15(38)$ & $5(13)$ & $8(20)$ & $9(23)$ & $4(10)$ & $4(10)$ & $5(13)$ & $5(13)$ & 70 \\
\hline $\begin{array}{l}\text { Return to } \\
\text { company } \\
\text { through agent }\end{array}$ & $20(50)$ & $18(45)$ & $18(45)$ & $18(45)$ & $17(43)$ & $21(53)$ & $19(48)$ & $14(35)$ & $12(30)$ & $12(30)$ & 169 \\
\hline $\begin{array}{l}\text { Destroy under } \\
\text { supervision }\end{array}$ & $4(10)$ & $3(8)$ & $3(8)$ & $3(8)$ & $4(10)$ & $2(5)$ & $2(5)$ & $1(3)$ & $1(3)$ & $1(3)$ & 24 \\
\hline Recycling & - & - & - & - & - & - & $2(5)$ & - & - & - & 2 \\
\hline Incinerate & - & - & - & - & - & - & - & - & $2(5)$ & - & 2 \\
\hline Total responses & 54 & 48 & 53 & 47 & 37 & 42 & 47 & 30 & 25 & 27 & 410 \\
\hline
\end{tabular}

Table 4: Pharmacists perception about medicinal waste disposal.

\begin{tabular}{|llll|}
\hline Item & Response & N $(\%)$ & N $(\%)$ \\
\hline & & As trash & To the sink \\
\hline \multirow{4}{*}{$\begin{array}{l}\text { On the harm to the } \\
\text { environment by } \\
\text { substandard disposal }\end{array}$} & No damage & $07(17.9)$ & $06(16.6)$ \\
& Mild damage & $01(2.5)$ & $02(5.5)$ \\
& Moderate damage & $08(20.5)$ & $06(16.6)$ \\
\cline { 2 - 4 } & Severe damage & $22(56.4)$ & $18(50)$ \\
\cline { 2 - 4 } & Don't know & $01(2.5)$ & $04(11.1)$ \\
\cline { 2 - 4 } & Total responses & 39 & 36 \\
\hline
\end{tabular}




\begin{tabular}{|c|c|c|c|}
\hline Item & Response & $\mathbf{N}(\%)$ & $\mathbf{N}(\%)$ \\
\hline \multirow{5}{*}{$\begin{array}{l}\text { On individual } \\
\text { responsibility on the } \\
\text { harm }\end{array}$} & & Harm to environment & Harm to living beings \\
\hline & Strongly agree & $18(45)$ & $19(47.5)$ \\
\hline & Agree & $18(45)$ & $17(42.5)$ \\
\hline & Unsure & $04(10)$ & $04(10)$ \\
\hline & Total responses & 40 & 40 \\
\hline \multirow{4}{*}{$\begin{array}{l}\text { On the need for a national } \\
\text { disposal scheme }\end{array}$} & Yes definitely & $29(72.5)$ & - \\
\hline & Yes, to some extent & $09(22.5)$ & - \\
\hline & Undecided & $02(5)$ & - \\
\hline & Total responses & 40 & - \\
\hline \multirow{4}{*}{ On conducting audits } & Yes definitely & $29(74.3)$ & - \\
\hline & Yes, to some extent & $08(20.5)$ & - \\
\hline & Undecided & $02(5.1)$ & - \\
\hline & Total responses & 39 & - \\
\hline \multirow{5}{*}{$\begin{array}{l}\text { On having a separate area } \\
\text { to store UM }\end{array}$} & Yes definitely & $18(47.3)$ & - \\
\hline & Yes, to some extent & $06(15.7)$ & - \\
\hline & Undecided & $05(13.1)$ & - \\
\hline & Not really & 09 (23.6) & - \\
\hline & Total responses & 38 & - \\
\hline \multirow{3}{*}{ On willing to accept $\mathrm{UM}$} & Yes & $08(28.5)$ & - \\
\hline & No & $20(71.4)$ & - \\
\hline & Total responses & 28 & - \\
\hline
\end{tabular}

Table 5: Preparedness of pharmacies to accept UM.

\begin{tabular}{|c|c|}
\hline Item & $\mathbf{N}(\%)$ \\
\hline \multicolumn{2}{|c|}{ Has a separate section to store UM (n=38) } \\
\hline Yes & $24(60)$ \\
\hline No & $14(35)$ \\
\hline \multicolumn{2}{|c|}{ Already accepts UM (n=39) } \\
\hline Accept all & $8(20)$ \\
\hline Depends on the type & $5(13)$ \\
\hline Not at all & $26(65)$ \\
\hline \multicolumn{2}{|c|}{ Pharmacy is suitable to accept UM (n=38) } \\
\hline Yes & $15(38)$ \\
\hline No & $23(58)$ \\
\hline \multicolumn{2}{|c|}{ Regular audits of UM are conducted $(n=38)$} \\
\hline Yes & $24(60)$ \\
\hline No & $14(35)$ \\
\hline
\end{tabular}

\section{DISCUSSION}

This study assessed the knowledge, practice and perceptions of the pharmacists regarding UM disposal in Sri Lanka. Previously, authors conducted a study to assess the same among patients. ${ }^{8}$ Overall, this study results reflected substandard knowledge, practices and perceptions among pharmacists on UM disposal and wide variation of practices indicating lack of a common guideline.

Even in the developed countries pharmacist's contribution towards UM disposal seems unsatisfactory. ${ }^{9}$ In a study conducted in Iraq, more than two-thirds $(65.9 \%)$ of the participants had agreed to return UM to the source compared to a $30 \%$ in our study. ${ }^{10}$ In a Nigerian study, $18.0(23.4 \%)$ complied fully with the National Guidelines, while $17.0(22.1 \%)$ complied partially and $42.0(54.5 \%)$ did not comply at all. Majority of the respondents in this study $(71.4 \%)$ had suggested to have a state-run disposal system which is in agreement with our study results $(72.5 \%) .{ }^{11}$ In a study conducted among medical and paramedical students and professionals in India, $89 \%$ of the participants were aware about the negative impact of improper disposal compared to $79.4 \%$ in our results. ${ }^{12}$ Another study from India reported that only a $58 \%$ of the participants believed improper disposal is intimately connected to environmental pollution. ${ }^{13}$ This shows that the level of knowledge and perceptions can vary according to the background.

The observed discrepancy between knowledge and the practice may be due to lack of a proper UM management system in place. This is quite similar to the status in Kuwait. ${ }^{6}$ Therefore, authors can hypothesise that the substandard practice can be improved by placing a structured program to collect UM. However, in a study conducted in Lagos metropolis, majority of the respondents had good knowledge (78.2\%), good reported practices $(90.4 \%)$, but relatively poor observed practices $(66.9 \%) .{ }^{14}$ Lack of an implemented program has contributed significantly to lower the standards of UM waste management in Romania. ${ }^{15}$ In Serbia, only $76.5 \%$ of pharmacies collected UM. ${ }^{16}$ There can be variation in the availability of UM disposal programs within a country. This encourages to have a centralised monitoring mechanism.

In many developed countries, there are established programs for UM handling. In the US, FDA has published a disposal protocol on their website for citizens to follow, if their community does not have a return program. In the US, health authorities need to develop disposal programs as part of the health strategies and policies to promote proper UM disposal and the pharmacists have to take a proactive role to ensure safe disposal of UM. They also have suggested that a collaborative effort between all the parties in the health care hierarchy is mandatory. 
Established and applied laws, along with community awareness would make the program easily achievable. ${ }^{17}$ In a previous review, authors suggested a possible framework for UM management in Sri Lanka and it is important to apply customised policies from the guidelines practiced in other countries. ${ }^{18}$

As the pharmacists are not willing to accept UM, it may be suitable to have common colleting centers in public places such as hospital clinics and super markets with necessary precautions and instructions. Not assessing the reasons for their refusal is a drawback in this study. A monitoring process would help to overcome poor compliance with the proper practice of UM disposal. A pilot project in selected institutions will give a more comprehensive feedback on UM management.

\section{CONCLUSION}

The level of knowledge, practices and perceptions among pharmacists on unwanted medicines disposal was substandard and needs attention. Authors recommend that formal education on UM disposal, a proper scheme to manage UM, National Guidelines on UM disposal and a monitoring processes should be implemented through a national policy.

\section{ACKNOWLEDGEMENTS}

Authors would like to acknowledge the support given by the chief pharmacists in peripheries for data collection.

\section{Funding: No funding sources}

Conflict of interest: None declared

Ethical approval: The ethics approval was obtained from the Ethics Review Committee, Faculty of Medicine, Colombo (Ref No: EC-12-190)

\section{REFERENCES}

1. Chartier Y, Emmanuel J, Pieper U. eds. Safe management of wastes from health-care activities. WHO; 2014: 308

2. Pilot study of pharmaceuticals and personal care products in fish tissue, EPA USA 2009. Available at: https://www.epa.gov/fish-tech/pilot-studypharmaceuticals-and-personal-care-products-fishtissue. Accessed on $10^{\text {th }}$ September 2019.

3. Guidelines for safe disposal of unwanted pharmaceuticals in and after emergencies, WHO 1999. Available at: http://www.who.int/water_ sanitation_health/medicalwaste/unwantpharm.pdf. Accessed on $11^{\text {th }}$ September 2019.

4. Persson M, Sabelström E, Gunnarsson B. Handling of unused prescription drugs-knowledge, behaviour and attitude among Swedish people. Environ Int. 2009;35(5):771-4.

5. Tong AY, Peake BM, Braund R. Disposal practices for unused medications in New Zealand community pharmacies. J Prim Health Care. 2011;3(3):197-203.
6. Abahussain EA, Ball DE, Matowe WC. Practice and opinion towards disposal of unused medication in Kuwait. Med Princ Pract. 2006;15(5):352-7.

7. Kidd KA, Blanchfield PJ, Mills KH, Palace VP, Evans RE, Lazorchak JM, et al. Collapse of a fish population after exposure to a synthetic estrogen. Proc Natl Acad Sci. 2007;104(21):8897-901.

8. Bataduwaarachchi VR, Thevarajah R, Weeraratne CL. Medication waste disposal practices among patients attending selected outpatient departments in a tertiary care institution: a cross sectional survey. Int J Basic Clin Pharmacol. 2018;7(5):888.

9. Bekker CL, Gardarsdottir H, Egberts AC, et al. Pharmacists' activities to reduce medication waste: an international survey. Pharm (Basel, Switzerland) 2018;6(3):94.

10. Albaroodi KA, Albaroodi, Ibrahim KA. Pharmacists' knowledge regarding drug disposal in Karbala. Pharm. 2019;7(2):57.

11. Michael I, Ogbonna B, Sunday N, Anetoh M, Matthew O. Assessment of disposal practices of expired and unused medications among community pharmacies in Anambra State southeast Nigeria: a mixed study design. J Pharm Policy Pract. 2019;12(1):12.

12. Raja S, Mohapatra S, Kalaiselvi A, Rani RJ. Awareness and disposal practices of unused and expired medication among health care professionals and students in a tertiary care teaching hospital. Biomed Pharmacol J. 2018;11(4):2073-8.

13. Suruchi A, Aditya R. Minimizing pharmaceutical waste: The role of the pharmacist. J Young Pharm 2014;6(3):14-9.

14. Chinwe ND. Knowledge and practices of pharmaceutical waste management among community pharmacists in Lagos metropolis. Clin Exp Pharmacol. 2016;6(2):68.

15. Bungau S, Tit D, Fodor K, Cioca G, Agop M, Iovan $\mathrm{C}$, et al. Aspects regarding the pharmaceutical waste management in Romania. Sustainabil. 2018;10(8):2788.

16. Manojlović J, Jovanović V, Georgiev AM, Tesink JG, Arsić T, Marinković V. Pharmaceutical waste management in pharmacies at the primary level of health care in Serbia-Situation Analysis. Indian $\mathbf{J}$ Pharm Educ Res. 2015;49:106-11.

17. Imad EM, Asim AE, Tasneem JM, Wadha MM, Bhagavathula AS. Management of post-consumer pharmaceutical waste: an overview. SOJ Pharm Pharm Sci. 2017;4(5):1-5.

18. Bataduwaarachchi V, Weeraratne C. Global medication waste management practices: challenges and opportunities in developing countries. Int J Basic Clin Pharmacol. 2016;5(6):2290-4.

Cite this article as: Bataduwaarachchi VR, Weerarathna CL, Paherathy A, Warapitiya DS, Sivapathasundaram M, Wickramarathna TN, et al. A survey on the knowledge, perceptions and practices regarding unwanted medicine disposal among pharmacists in Sri Lanka. Int J Basic Clin Pharmacol 2020;9:1002-6. 